\title{
PARIWISATA BERBASIS MASYARAKAT SEBAGAI PELESTARI TRADISI DI DESA SAMIRAN
}

\author{
Made Prasta Yostitia Pradipta ${ }^{1,2}$ \\ 1 Program Doktoral Kajian Pariwisata Universitas Gadjah Madha \\ 2 Sekolah Tinggi Pariwisata Sahid Surakarta \\ Email: madeprasta@mail.ugm.ac.id
}

\begin{abstract}
The purpose of this paper is to describe the exist traditions in Samiran Village and to study how far the people participation of Samiran Village as tradition preservers. A qualitative approach is used in this paper and described descriptively. Conducting literature studies, in-depth interviews, and observations is used in this paper. Assisted by participatory theory to analyze ho far the community participation as tradition preservers. The results show that the people of Samiran Village still carry out the sadranan and baritan traditions. The purpose of this tradition is to honor the ancestors, give thanks for the harvest, ask for blessings and a sense of mutual help. Community participation in tradition activities in Samiran Village consists of 2 types, namely active and passive participation. Direct participation carried on the tradition Sadranan, whereas indirect participation carried on the tradition baritan. With the concept of a community-based tourism, traditional activities can become a cultural tourist attraction. This paper proposes the role of the community as a preserver of tradition so that it is maintained and preserved. This paper also recommends a study on the role of the community as a preserver of other traditions that have not been mentioned by the author.
\end{abstract}

Keywords: Samiran Village, Community Based Tourism; Tradition, Tourist Attraction

\begin{abstract}
Abstrak
Tujuan makalah ini dibuat adalah untuk mendekripsikan tradisi-tradisi yang ada di Desa Samiran dan mengkaji sejauh mana partisipasi masyarakat Desa Samiran sebagai pelestari tradisi. Pendekatan kualitatif digunakan dalam makalah ini dan dijelaskan secara deskriptif. Untuk memahami dan menganalisis tradisi di Desa Samiran dengan melakukan studi kepustakaan, wawancara mendalam, dan observasi. Dibantu dengan teori partisipatif untuk menganalisis sejauh mana partisipasi dari masyarakat sebagai pelestari tradisi. Hasil penelitian menunjukkan masyarakat Desa Samiran masih melakukan tradisi sadranan dan baritan. Tujuan tradisi ini adalah untuk penghormatan kepada nenek moyang, rasa syukur hasil panen, meminta keberkahan dan rasa saling menolong. Partisipasi kegiatan tradisi masyarakat Desa Samiran terdiri dari 2 jenis yaitu partisipasi aktif dan pasif. Partisipasi langsung dilakukan pada tradisi sadranan sedangkan partisipasi tidak
\end{abstract}


langsung dilakukan pada tradisi baritan. Dengan konsep pendekatan pariwisata berbasis masyarakat, kegiatan tradisi bisa menjadi daya tarik wisata budaya. Makalah ini mengusulkan peran masyarakat sebagai pelestari tradisi agar tetap dijaga dan dilestarikan. Makalah ini juga merekomendasi kajian tentang peran masyarakat sebagai pelestari tradisi-tradisi lain yang belum disebutkan oleh penulis.

Kata Kunci: Desa Samiran, Pariwisata Berbasis Masyarakat; Tradisi, Daya Tarik Wisata

\section{A. PENDAHULUAN/INTRODUCTION}

Mengembangkan suatu desa wisata merupakan suatu strategi dari pemerintah dalam mendorong masyarakat sebagai pelaku utama dalam kepariwisataan. Pengembangan desa wisata layak dimiliki untuk kepentingan masyarakat tersebut. Hal ini sangat bergantung dari kesiapan masyarakat dalam mengelola potensi yang ada di desa mereka sebagai suatu aktifitas perekonomian. Masyarakat merupakan unsur terpenting dari suatu destinasi pariwisata dan masyarakat dapat menjadi penggerak suatu desa jika dikelola dan dikembangkan melalui konsep desa wisata.

Dalam konteks desa wisata yang mempunyai potensi daya tarik wisata budaya, menyaksikan atraksi wisata budaya menjadi salah satu tujuan utama untuk mengunjungi suatu daerah. Pelibatan masyarakat dalam suatu kegiatan dapat memberikan jalan dalam pengembangan, pemberdayaan, termasuk dalam pengembangan ekonomi dari kegiatan kepariwisataan. Kontribusi masyarakat merupakan hal yang wajib dilakukan, untuk menunjang terlaksananya pengelolaan pariwisata yang mengutamakan pemberdayaan dan pelestarian budaya. Oleh sebab itu, pengelolaan pariwisata diharapkan lebih mengarah pada keadilan, kesejahteraan, konservasi, dan pelestarian.

Pariwisata Indonesia adalah pariwisata yang berlandaskan asas kemasyarakatan yang berasal dari rakyat, oleh rakyat, dan untuk rakyat. Lebih jauh, konsep pariwisata berbasis masyarakat melibatkan masyarakat lokal dalam pengelolaan dan pengembangan pariwisata. Keterlibatan masyarakat baik secara sadar atau tidak yang memiliki potensi pariwisata memiliki keuntungan yang bisa didapat secara merata oleh komunitas di pedesaan/pesisir maupun di pulau-pulau terpencil (Darmawi, 2010). Konsep pariwisata berbasis masyarakat merupakan suatu pendekatan perencanaan yang partisipatif dalam pembangunan dan pengembangan (Hermawan, 2017; Kirom, Sudarmiatin, \& Putra, 2016; Nurdin, 2016). Dengan demikian konsep pariwisata berbasis masyarakat merupakan suatu pendekatan pengembangan wisata baik wisata alam, budaya, maupun buatan manusia, baik yang terlibat secara langsung maupun tidak langsung, secara sadar maupun tidak sadar yang menekankan pada peran aktif masyarakat lokal. Bentuk dari perhatian yang analitis tersebut adalah suatu ide yang tepat terhadap pengembangan dan perencanaan pariwisata yang acap kali mengabaikan hak dari masyarakat di daerah tujuan wisata (Andriani, Wibowo, \& Winarno, 2020).

Berikut adalah prinsip-prinsip pariwisata berbasis masyarakat sebagai alat untuk pengembangan masyarakat yaitu; 1) Kelestarian lingkungan terjamin; 2) Kebanggaan masyarakat ikut dipromosikan; 3) Keterlibatan sejak awal anggota masyarakat dalam setiap 
aspek; 4) Peningkatan kualitas hidup; 5) Mengakui, mendukung dan mempromosikan kepemilikan masyarakat atas pariwisata; 6) Melestarikan keunikan karakter dan budaya daerah setempat; 7) Menghargai perbedaan budaya dan martabat manusia; 8) Membina pembelajaran lintas budaya; 9) Mendistribusikan hasil yang didapat secara adil di antara anggota masyarakat; 10) Menyumbangkan perolehan pendapatan tetap untuk proyekproyek komunitas (Suansri, 2003).

Desa Wisata Samiran merupakan salah satu destinasi desa wisata di daerah Boyolali yang mempunyai semua potensi pariwisata mulai dari alam, budaya, maupun ciptaan manusia. Segala macam potensi yang ada di Desa Samiran merupakan suatu potensi yang dapat menjadi daya tarik wisata dan dengan pola perubahan perilaku wisatawan, maka desa wisata akan menjadi tujuan melakukan perjalanan. Kegiatan masyarakat berupa tradisi di Desa Samiran dapat menjadi potensi pariwisata budaya minat khusus yang bisa menarik wisatawan untuk datang berkunjung. Masyarakat menganggap hanya melakukan tradisi yang biasa mereka lakukan, akan tetapi mereka secara tidak sadar telah mengenalkan tradisi mereka ke masyarakat luas (Daniah, 2019). Oleh sebab itu, tradisi di Desa Samiran dapat dilihat dari dua sisi berbeda, di satu sisi tradisi merupakan suatu bentuk kegiatan yang terus dilakukan oleh masyarakat Desa Samiran dan di sisi lainnya adalah suatu kegiatan masyarakat yang belum menjadi perhatian masyarakat sebagai bagian dari pariwisata. Fokus dari makalah ini adalah pada 2 tradisi di Desa Samiran yang ditemukan selama observasi di Desa Samiran, yaitu tradisi Sadranan dan Baritan.

Dari latar belakang permasalahan diatas maka penulis tertarik untuk mengkaji konsep pariwisata masyarakat sebagai pelestari tradisi di Desa Samiran. Maka permasalahan penulisan ini adalah; 1) bagaimana bentuk tradisi sadranan dan baritan di Desa Samiran, 2) bagaimana partisipasi masyarakat Desa Samiran. Kajian tentang masyarakat sebagai pelestari tradisi Desa Samiran diharapkan dapat membantu memberikan gambaran kondisi bagaimana tradisi sebagai wisata budaya dapat menarik wisatawan untuk berkunjung dan dapat membangun image Desa Samiran sebagai pariwisata yang tidak hanya alam, dan buatan manusia akan tetapi juga wisata budaya. Oleh sebab itu, tujuan dalam makalah ini adalah 1) Mendeskripsikan tradisi yang ada di Desa Samiran dan 2) Mengkaji sejauh mana partisipasi masyarakat Desa Samiran sebagai pelestari tradisi.

\section{B. TEORI DAN METODE PENELITIAN/RESEARCH METHOD}

Teori yang digunakan dalam makalah ini adalah teori partisipasi yang digunakan untuk menjelaskan bagaimana bentuk partisipasi yang dilakukan masyarakat sebagai pelestari tradisi di Desa Samiran. Dalam teori partisipasi yang dilakukan masyarakat ada tingkatan yang berdeba, tergantung dari keaktifan masyarakat. Partisipasi dibagi menjadi enam yaitu antara lain; 1), partisipasi yang bersifat pasif (passive participation), 2) partisipasi yang bersifat aktif (active participation), 3) partisipasi karena paksaan (manipulative participation), 4), partisipasi karena adanya dorongan (indiced participation), 5) partisipasi dengan kekuasaan dan ancaman (coercive participation), dan 6) partisipasi secara spontan (spontaneous participation) (Tosun, 2000).

Pengumpulan data dalam makalah ini dilakukan dengan tiga cara yaitu; 1) Observasi ke Desa Samiran dan merekam kegiatan masyarakat disana untuk mendapatkan data 
penelitian, 2) Wawancara mendalam mendalam dengan warga setempat, Tetua Adat, dan Ketua Pokdarwis, dan 3) Studi pustaka digunakan untuk mendapatkan data sekunder meliputi buku-buku, arsip, gambar berupa foto, dan manuskrip yang relevan dengan tujuan makalah sebagai penyempurna data dari pengumpulan data sebelumnya.

Tehnik Pengolahan data sebagai berikut; 1) setelah data dikumpulkan dari studi pustaka, observasi, wawancara mendalam dengan warga setempat, Tetua Adat, dan Ketua Pokdarwis, lalu data di susun dan di reduksi berdasarkan tujuan dan apa yang dibutuhkan dalam makalah ini, 2) data yang sudah di edit lalu dipilah kemudian dianalisis sesuai dengan tujuan penelitian, dan 3) data disajikan lalu dilakukan dengan menafsirkan data untuk mendapatkan simpulan. analisis data yang digunakan dalam makalah ini adalah deskriptif kualitatif.

\section{HASIL DAN ANALISIS}

\section{GAMBARAN UMUM DESA SAMIRAN}

Desa Samiran adalah salah satu desa yang secara administratif berada di Kecamatan Selo, Kabupaten Boyolali Provinsi Jawa Tengah. Dari hasil observasi yang dilakukan di Pokdarwis Guyub Rukun Desa Samiran, desa ini terletak diantara dua gunung yaitu Gunung Merapi dan Merbabu. Dengan ketinggian kurang lebih 1500-1600 meter diatas permukaan laut dengan suhu kurang lebih 13-16 derajat celcius. Beikut merupakan peta wilayah Desa Samiran.

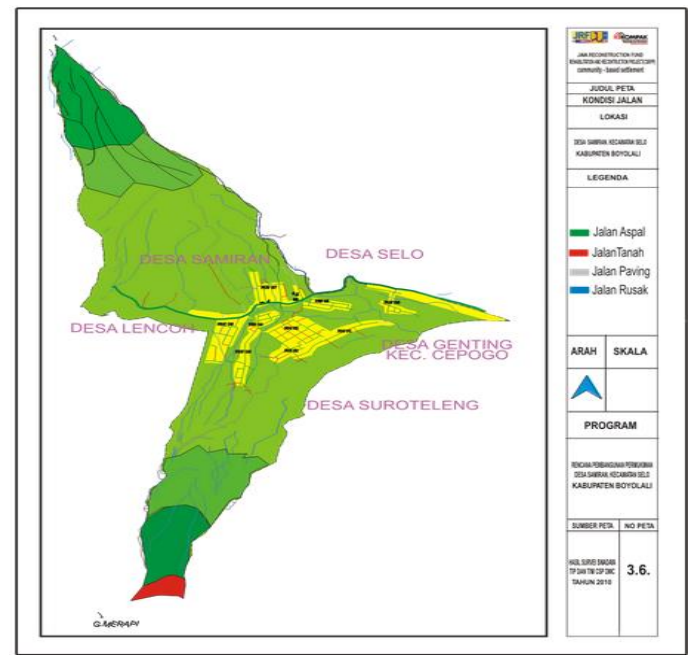

\section{Gambar 1. Peta wilayah Desa Samiran Sumber: Pokdarwis Guyub Rukun Desa Samiran}

Dapat dilihat dari peta wilayah tersebut bahawa batas wilayah desa samiran terbagi dalam empat arah mata angin, yaitu sebelah utara berbatasan langsung dengan Desa Selo, Kecamatan Selo, sebelah selatan berbatasan dengan Desa Suroteleng, Kecamatan Selo, sebelah barat dengan Desa Lencoh di Kecamatan Selo, dan Sebelah timur Desa Genting, Kecamatan Cepogo. Sedangkan pembagian wilayah Desa Samiran dapat dilihat dalam tabel 1. Berikut; 


\begin{tabular}{cl}
\hline No & \multicolumn{1}{c}{ Dukuh } \\
\hline $\mathbf{1}$ & Blumbangsari \\
\hline $\mathbf{2}$ & Gebyog \\
\hline $\mathbf{3}$ & Jarakan \\
\hline $\mathbf{4}$ & Kuncen \\
\hline $\mathbf{5}$ & Ngablak \\
\hline $\mathbf{6}$ & Ngaglik \\
\hline $\mathbf{7}$ & Pentongan \\
\hline $\mathbf{8}$ & Plalangan \\
\hline $\mathbf{9}$ & Pojok \\
\hline $\mathbf{1 0}$ & Salam \\
\hline $\mathbf{1 1}$ & Samiran \\
\hline $\mathbf{1 2}$ & Segaran \\
\hline $\mathbf{1 3}$ & Tegalsruni \\
\hline $\mathbf{1 4}$ & Tretes
\end{tabular}

Tabel 1. Pembagian Wilayah Desa Samian Sumber: Pribadi

Informasi dari tabel 1 dan 2 tentang pembagian wilayah dan populasi di Desa Samiran tersebut menunjukkan bahwa jumlah populasi masyarakat khususnya di Desa Samiran memiliki 3725 jiwa di tahun 2017, 3726 jiwa di tahun 2018, 3851 jiwa di tahun 2019, dan 3884 jiwa di tahun 2020.

\begin{tabular}{llllll}
\hline \multirow{2}{*}{ No } & Jenis Kelamin & \multicolumn{4}{c}{ Jumlah Jiwa } \\
\cline { 3 - 6 } & & 2017 & 2018 & 2019 & 2020 \\
\hline 1. & Laki-laki & 1904 & 1909 & 1945 & 1938 \\
\hline $\mathbf{2 .}$ & Perempuan & 1821 & 1817 & 1906 & 1946 \\
\hline & Jumlah & $\mathbf{3 7 2 5}$ & $\mathbf{3 7 2 6}$ & $\mathbf{3 8 5 1}$ & $\mathbf{3 8 8 4}$
\end{tabular}

Tabel 2. Jumlah populasi di Desa Samiran

Sumber: Pribadi

\section{TRADISI DESA SAMIRAN}

\section{Penghormatan Kepada Leluhur/ Sadranan}

Tradisi penghormatan kepada leluhur atau biasa orang sebuat adalah Upacara Sadranan adalah salah satu acara turun temurun yang ada di masyarakat lereng gunung Merapi dan Merbabu termasuk Desa Samiran. Dari hasil observasi menunjukkan bahwa 
kegiatan ini dilakukan setiap bulan ruwah atau dalam islam sering disebut bulan Nifsu Sya'ban (Gambar 2).

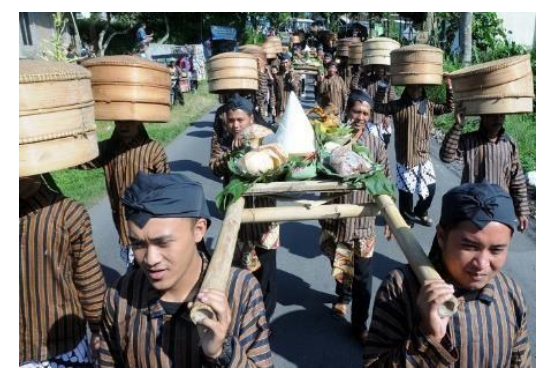

\section{Gambar 2 Tradisi Sadranan Sumber: Pribadi}

Dari gambar 2 diatas menunjukkan bahwa dalam kegiatan tradisi sadranan ini setiap keluarga dari masyarakat Desa Samiran membawa makanan dari rumah yang telah dimasak atau biasa disebut tenongan yang kemudian dibawa ke makam untuk dilaksanakan upacara mengirim doa kepada para leluhur, kemudian makanan tersebut dibawa pulang kembali kerumah masing-masing dan dibagi ke keluarga, sanak saudara, dan teman yang datang ke rumah. Teman atau keluarga diundang untuk datang bersilaturahmi dan makan makanan yang telah mereka sediakan. Acara ini sebagai salah satu acara yang sangat menarik dan sebagai ajang untuk bersilaturahmi antar keluarga atau teman. Hasil wawancara yang didapat dari salah satu informan mengatakan bahwa sadranan merupakan tradisi yang sering dilakukan oleh masyarakat dan mempunyai tujuan yaitu untuk memberikan penghormatan kepada leluhur yang telah melahirkan mereka dan rasa syukur masih diberikan kehidupan. Hasil wawancara dari informan yang sama juga mengatakan bahwa tradisi ini merupakan suatu kegiatan yang menarik wisatawan untuk mengenal adat, budaya, dan kearifan lokal masyarakat.

\section{Baritan atau Sedekah Bumi}

Tradisi Baritan atau sedekah bumi merupakan salah satu kegiatan tradisi unik yang dilakukan di Desa Samiran, karena tradisi ini dilakukan secara privasi dan tidak banyak yang tahu, kegiatan ini dilakukan setiap menjelang bulan Suro atau bulan Muharam (gambar 3). Acara ini dilakukan dengan cara yang cukup unik dan sedikit mistis, karena beberapa orang pilihan yang telah dipilih oleh tetua adat dari dukuh tersebut harus berjalan kaki dengan tanpa busana dari tempat tetua desa kemudian menuju 5 titik pojok desa dengan berjalan kaki sambil membawa sesaji yang telah di persiapkan. 5 titik sesajen diantaraya adalah bagian pojok bawah kanan, pojok bawah kiri atas dan bawah kemudian satu titik di tengah desa, acara tersebut dilakukan selepas shalat isya. Wujud dari partisipasi masyarakat adalah dalam bentuk partisipasi masyarakat tidak langsung (pasif) yaitu satu desa semua diwajibkan untuk mematikan lampu dan penerangan yang ada di desa tersebut dan tinggal di rumah, dimana lampu dan semua pencahayaan harus dimatikan setidaknya sampai jam 23.59 WIB. Tradisi ini persis seperti ritual nyepi di Bali, dimana semua lampu dan pencahayaan rumah harus dimatikan agar sunyi senyap. Tujuannya adlaah agar masyarakat berintrospeksi diri. Penulis berkesempatan untuk mendapatkan ijin dari tetua adat agar bisa ikut merasakan prosesi dari tradisi adat ini. 


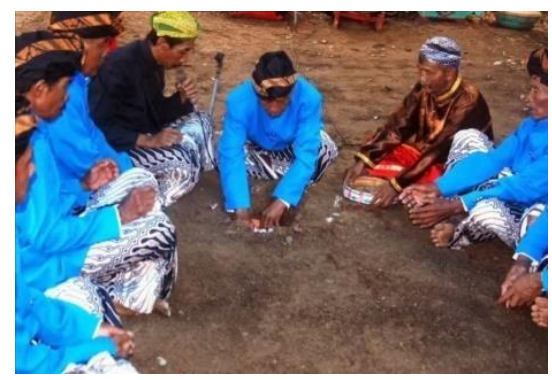

\section{Gambar 3 Ritual adat Baritan atau Sedekah Bumi Sumber: Pribadi}

Tradisi baritan ini diartikan dengan suatu perayaan adat sebagai bentuk rasa syukur yang diberikan kepada Tuhan. Dari hasil analisis penelitian di lapangan dan sebagaimana mengacu pada gambar 3 menunjukkan bahwa ritual adat sedekah bumi dilaksanakan oleh masyarakat terkait dengan penghormatan kepada leluhur atau penguasa alam. Dalam perspektif orang Jawa-Hindu tradisi ini merupakan persembahan untuk dewi sri atau dewi kesuburuan (Hidayatulloh, 2013). Mereka sudah tinggal di bumi yang disediakan Tuhan, mereka boleh bercocok tanam di bumi (tanah) sebagai media, bahkan sampai bisa memanen hasil yang melimpah dari bumi dan bisa menikmati hasil dari bercocok tanam sebagai wilayah yang mempunyai potensi di bidang pertanian dan peternakan. Oleh karena itu mereka merasa perlu bersyukur atas segala rezeki yang mereka terima yang merupakan hasil dari bumi. Unsur budaya ini dapat diangkat menjadi salah satu daya tarik wisata minat khusus, karena disini hanya beberapa orang yang mendapatkan ijin dari tetua aadat yang bisa ikut untuk mengabadikan prosesi tersebut.

\section{BENTUK PARTISIPASI MASYARAKAT DESA SAMIRAN}

Partisipasi masyarakat selalu menjadi penunjang utama dalam setiap kegiatan merupakan suatu wujud pelestarian tradisi. Tujuan utama dari pelestarian tradisi lebih menitikberatkan pada kepentingan masyarakat lokal dan diharapkan dapat memberi manfaat yang besar bagi masyarakat lokal. Berdasarkan observasi, partisipasi masyarakat yang ikut dalam kegiatan tradisi di Desa Samiran membuktikan bahwa ada dua bentuk partisipasi, yaitu partisipasi langsung (aktif) dan tidak langsung (pasif). Bentuk partisipasi langsung (aktif) dapat dilihat dari tradisi sadranan seperti contoh, mereka berkunjung ke makam leluhur dan mendoakan leluhur, setelah dari makam mereka pulang kerumah untuk menyambut tamu yang datang berkunjung. Dalam setiap proses kegiatan tradisi suatu daerah, partisipasi masyarakat secara langsung wajib dilakukan demi tercapainya tujuan dan pelestarian tradisi tersebut. Partisipasi ideal yang dilakukan oleh masyarakat adalah menumbuhkan semangat untuk ikut dalam berpartisipasi dalam semua kegiatan, sehingga masyarakat dapat saling menjaga, berbagi, dan akhirnya proses itu dapat dirasakan secara adil. Tingkatan hirarki partisipasi masyarakat paling tinggi dan kuat adalah partisipasi yang berada pada tingkat kendali masyarakat, yang artinya kekuasaan akan pelestarian tradisi sepenuhnya berada di tangan masyarakat (Lestari, Armawi, \& Muhamad, 2016).

Selain partisipasi langsung (aktif), masyarakat Desa Samiran juga secara tidak sadar ikut berpartisipasi meskipun secara tidak langsung (pasif). Hal ini terwujud dalam bentuk menjaga keamanan dan kenyamanan lingkungan selama kegiatan tradisi, seperti contohnya adalah pada tradisi adat baritan. Keamanan dan kenyamanan merupakan 
bagian yang tidak kalah penting dari proses kegiatan masyarakat, karena sangat berpengaruh kepada tingkat ritual pada saat prosesi tradisi dilakukan. Partisipasi masyarakat baik secara aktif maupun pasif menjadi penunjang dalam pelestarian tradisi di Desa Samiran. Disinilah peranan masyarakat sebagai pelestari tradisi sangat dibutuhkan. Sarana utama yang harus diperhatikan bagi berhasilnya pelestarian tradisi adalah masyarakat dan sarana pendukung adalah aktivitas tradisi untuk menjaga budaya lokal mereka. Dengan adanya tingkat kerjasama antar warga ditambah dengan saling menjaga menjadikan masyarakat Desa Samiran semakin kompak dan solid.

Salah satu tokoh Pokdarwis dan juga masyarakat Desa Samiran (Solikhin) mengatakan bahwa partisipasi masyarakat di Desa Samiran dalam mengadakan kegiatan kebudayaan apapun pasti akan disambut dengan baik dan antusias yang tinnggi. Hal ini juga ditunjang dengan pemeliharaan mengenai kearifan lokal yang berjalan seirama dengan aktivitas pariwisata dan pelestarian budaya. Setiap diadakan kegiatan kebudayaan di masyarakat merupakan sesuatu yang sangat ditunggu-tunggu setiap perayaannya.

Tingkat partisipasi masyarakat dalam menjaga tradisi mereka wajib diapresiasi untuk tetap eksis dan lestari. Keunikan tradisi di Desa Samiran bisa menjadi modal budaya dalam pengembangan pariwisata khususnya daya tarik wisata budaya. Dengan hadirnya konsep pariwisata berbasis masyarakat yang berprinsip pada pelestarian budaya dan pengembangan sumber daya manusia, diharapkan dapat meningkatkan peran serta masyarakat baik orang tua maupun anak-anak muda. Tidak dipungkiri, pariwisata juga bisa memberikan dampak yang negatif kepada Desa Samiran seperti contohnya adalah westernisasi budaya, perusakan alam, vandalism, kotor, dan lain sebagainya. Akan tetapi, dengan konsep pariwisata berbasis masyarakat diharapkan terjalin kerjasama yang baik antar warga dan dengan manajemen yang baik dapat meminimalisir dampak negatif tersebut.

Hal senada juga di sampaikan oleh tetua adat Desa Samiran (Simbah Klumpuk) menyatakan bahwa dengan keyakinan bahwa budaya lokal akan memiliki daya tahan terhadap pengaruh negatif pariwisata apabila seluruh elemen masyarakat memiliki rasa kepedulian terhadap nilai-nilai budaya lokal dengan terus menerus melestarikan berbagai kegiatan seminar budaya lokal sebagai wujud pelestarian budaya.

"Budoyo kui mas, ora iso ilang seko masyarakat selagi masyarakat iso ngerti marang apike budoyo lan manfaate budoyo kanggo kelangsungan urip ono ing ngalam ndunyo iki "

"Budaya itu mas. Tidak bisa hilang dari masyarakat selagi masyarakat mengerti akan baiknya budaya dan manfaatnya budaya bagi keberlangsungan hidup di dunia ini"

Dari observasi di lapangan, masyarakat Desa Samiran menjalankan tradisi-tradisi tersebut sebagai salah satu wujud dari kearifan lokal. Mereka mungkin sudah ditinggalkan oleh nenek moyang mereka, tetapi tradisi yang ditinggalkan oleh nenek moyang mereka masih tetap bertahan dan lestari di setiap keturunannya. Dari dua tradisi yang disebutkan di atas maka sadranan adalah tradisi yang paling bisa untuk dijadikan potensi pariwisata. Karena sadranan merupakan suatu tradisi yang terbuka untuk umum dan bisa dinikmati wisatawan yang berkunjung dengan disuguhkan keramahan dari warga lokal. Dengan adanya potensi tersebut ditambah dengan adanya konsep wisata berbasis masyarakat diharapkan dapat melestarikan tradisi mereka. 


\section{PARIWISATA BERBASIS MASYARAKAT SEBAGAI PELESTARI TRADISI DI DESA SAMIRAN}

Masyarakat sebagai pelestari tradisi yang dilandasi oleh kesadaran untuk memahami, menjaga, dan melestarikan warisan budaya lokal diharapkan mampu untuk melestarikan budaya dan tradisi yang ada. Bahkan, masyarakat sebagai penentu keputusan mempunyai hak kuasa atas tradisi mereka tetap lestari atau punah. Semua unsur masyarakat mulai dari warga biasa sampai tetua adat di Desa Samiran bersamasama bertanggung jawab dalam menjaga tradisi serta nilai-nilai budaya lokal mereka.

Pengembangan budaya dalam pengelolaan wisata berbasis masyarakat dilakukan dengan menerapkan nilai-nilai budaya dalam setiap kegiatan masyarakat yang bertujuan untuk melindungi budaya lokal mereka. Hal ini sesuai dengan prinsip pariwisata berbasis masyarakat yaitu; 1) Kelestarian lingkungan terjamin; 2) Kebanggaan masyarakat ikut dipromosikan; 3) Keterlibatan sejak awal anggota masyarakat dalam setiap aspek; 4) Peningkatan kualitas hidup; 5) Mengakui, mendukung dan mempromosikan kepemilikan masyarakat atas pariwisata; 6) Melestarikan keunikan karakter dan budaya daerah setempat; 7) Menghargai perbedaan budaya dan martabat manusia; 8) Membina pembelajaran lintas budaya; 9) Mendistribusikan hasil yang didapat secara adil di antara anggota masyarakat; 10) Menyumbangkan perolehan pendapatan tetap untuk proyekproyek komunitas.

Berpegang pada prinsip pariwisata berbasis masyarakat yang diutarakan diatas, maka Desa Samiran secara tidak sadar telah mengacu kepada hampir semua prinsip konsep pariwisata berbasis masyarakat tersebut sebagai pelestari tradisi dan kearifan lokal. Dengan konsep pariwisata berbasis masyarakat maka dirasa mampu untuk mengembangkan pariwisata yang berbasis masyarakat sebagai pelestari tradisi budaya lokal.

\section{SIMPULAN/CONCLUSION}

Tradisi upacara adat yang ditemui penulis yaitu sadranan dan baritan merupakan tradisi adat yang sering dilakukan oleh masyarakat Desa Samiran dengan tujuan untuk penghormatan kepada nenek moyang, rasa syukur, rasa syukur hasil panen, meminta keberkahan dan rasa saling menolong. Tradisi Sadranan dilakukan dengan tujuan penghormatan kepada leluhur yang dibuktikan dengan datang ke makam leluhur untuk berziarah. Sedangkan tradisi Baritan dilakukan dengan tujuan mensyukuri hasil panen yang masyarakat terima yang dibuktikan dengan mengelilingi desa dan hasil panen tersebut dibagikan ke warga desa.

Hasil penelitian menemukan bahwa partisipasi masyarakat dalam kegiatan kebudayaan masih terus dilaksanakan karena warisan budaya yang harus tetap dijaga dan dilestarikan dari generasi ke generasi selanjutnya. Dari hasil observasi mengungkap bahwa tradisi tersebut bisa menjadi potensi daya tarik wisata budaya. Dengan adanya potensi wisata tersebut maka akan melengkapi daya tarik wisata yang ada di Desa Samiran. Peran masyarakat sebagai pelestari disini adalah sebagai pendukung suatu kegiatan kebersamaan yang menekankan pada keuntungan bersama. Adanya Partisipasi masyarakat baik itu secara aktif maupun pasif dapat menunjang konsep pengembangan pariwisata berbasis masyarakat di Desa Samiran. Dari hasil observasi di lapangan, mengungkapkan bahwa tradisi sadranan lebih dominan dalam pengembangan pariwisata berbasis masyarakat dibanding dengan baritan karena wisatawan bisa merasakan langsung tradisi tersebut sedangkan baritan tidak. 
Makalah ini belum mengkaji tentang semua tradisi yang ada di Desa Samiran, tradisi yang di deskripsikan hanya terbatas pada sadranan dan baritan. Makalah ini juga belum mengkaji peran pemerintah mengenai kebijakan dan promosi budaya. Selain itu, peran pemerintah diharapkan dapat membuat acara atau event yang kedepanya dapat membuat pelestarian dan pengembangan tradisi semakin berkembang dan dikenal oleh masyarakat luas. Oleh karena itu makalah ini dapat menjadi bahan rujukan sementara untuk dapat menjadi fondasi mengenali bagaimana adat istiadat di Desa Samiran. Makalah ini merekomendasikan perlunya penelitian lanjutan untuk memahami tradisi yang lain di Desa Samiran dan bagaimana perspektif pemerintah terhadap tradisi-tradisi di Desa Samiran.

\section{E. UCAPAN TERIMAKASIH}

Saya mengucapkan banyak terima kasih kepada segenap pihak, khususnya pihak Pokdarwis Guyub Rukun dan warga sekitar yang menjadi narasumber yang telah memberikan segalanya, baik secara langsung ataupun tidak langsung terkait informasi kepariwisataan Desa Samiran. Ucapan yang sama, saya berikan untuk Bapak Dr. Ir. Djoko Wijono, M. Arch untuk bimbingannya dalam penulisan makalah ini. Semoga masyarakat Desa Samiran ke depan lebih berkembang dan dikenal luas.

\section{DAFTAR REFERENSI/REFERENCES}

\section{Journal Article:}

Andriani, R. A., Wibowo, A. A., \& Winarno, J. (2020). Analisis Kebutuhan Masyarakat dalam Pengembangan Dewi Sambi (Desa Wisata Samiran Boyolali) di Desa Samiran, Kecamatan Selo, Kabupaten Boyolali. Jurnal Nasional Pariwisata, 12(2), 82-86.

Daniah, D. (2019). Nilai Kearifan Lokal Didong Dalam Upaya Pembinaan Karakter Peserta Didik. Jurnal Pendidikan.

Darmawi, E. J. J. I. I. (2010). Pengembangan Kepariwisataan Berbasis Masyarakat di Kota Bengkulu. Jurnal Ilmiah IDEA, 4.

Hermawan, H. J. M. W. (2017). Pengaruh daya tarik wisata, keselamatan, dan sarana wisata terhadap kepuasan serta dampaknya terhadap loyalitas wisatawan: studi Community Based Tourism di Gunung Api Purba Nglanggeran. Media Wisata, 15(1). doi:https://doi.org/10.36276/mws.v15i1.213

Hidayatulloh, F. S. J. E. H. J. B. I. (2013). Sedekah Bumi Dusun Cisampih Cilacap. EL HARAKAH Jurnal Budaya Islam, 15(1), 1-17. doi:https://doi.org/10.18860/el.v15i1.2669

Kirom, N. R., Sudarmiatin, S., \& Putra, I. W. J. A. J. J. P. T., Penelitian, dan Pengembangan. (2016). Faktor-Faktor Penentu Daya Tarik Wisata Budaya Dan Pengaruhnya Terhadap Kepuasan Wisatawan. Jurnal Pendidikan: Teori, Penelitian, dan Pengembangan, 1(3), 536-546. doi:http://dx.doi.org/10.17977/jp.v1i3.6184

Lestari, G., Armawi, A., \& Muhamad, M. J. J. K. N. (2016). Partisipasi pemuda dalam mengembangkan pariwisata berbasis masyarakat untuk meningkatkan ketahanan sosial budaya wilayah (Studi di Desa Wisata Pentingsari, Umbulharjo, Cangkringan, Sleman, DI Yogyakarta). Jurnal Ketahanan Nasional, 22(2), 137157. doi:https://doi.org/10.22146/jkn.17302 
Nurdin, N. J. J. M. P. (2016). Strategi Pengembangan Pariwisata Berbasis Masyarakat Di Pulau Samalona, Makassar. JUMPA. Master Pariwisata, 3, 175-189.

Suansri, P. (2003). Community Based Tourism Handbook. In. Retrieved from https://www.mekongtourism.org/wp-content/uploads/REST-CBT-Handbook2003.pdf

Tosun, C. J. T. m. (2000). Limits to community participation in the tourism development process in developing countries. 21(6), 613-633. doi:https://doi.org/10.1016/S0261-5177(00)00009-1 